\title{
Begeleiding van portfoliogebruik in de medische basis- en vervolgopleiding*
}

\author{
H. Dekker, E. Driessen, E. ter Braak, F. Scheele, J. Slaets, T. van der Molen, J. Cohen-Schotanus
}

\section{Samenvatting}

Inleiding: Uit onderzoek blijkt dat bij portfoliogebruik begeleiding een cruciale rol speelt. Het doel van dit artikel is te onderzoeken op welke wijze deze begeleiding geïmplementeerd is in de medische basis- en vervolgopleidingen.

Methode: De resultaten van zes interviews met voorlopers in de toepassing van portfolio's in het medisch onderwijs zijn gebruikt om een vragenlijst te ontwikkelen; deze vragenlijst is verspreid onder 30 coördinatoren van portfolioprogramma's binnen de basis- en vervolgopleidingen in Nederland en Vlaanderen.

Resultaten: Uit de interviews kwamen vier hoofdaspecten van het portfoliobegeleidingsproces naar voren: onderwijskundig doel, individuele voortgangsgesprekken, groepsbijeenkomsten en karakteristieken van de begeleiders. Op basis van de antwoorden op de vragenlijst zijn 16 portfolioprogramma's uit de basisopleidingen en 14 portfolio-implementaties uit de vervolgopleidingen beschreven. Het geven van feedback en het stimuleren van reflectie zijn de hoofddoelen van het begeleidingsproces. Het voeren van individuele voortgangsgesprekken blijkt een favoriete begeleidingsmethode te zijn. Onderwijs in kleine groepen om reflectief portfoliogebruik te ondersteunen, komt vooral voor in de basisopleiding. De begeleiders zijn meestal clinici die een training hebben gehad ter voorbereiding op deze begeleidende taak.

Conclusie: Deze studie geeft een overzicht van de diverse wijzen waarop de begeleiding bij het portfoliogebruik vormgegeven is. (Dekker H, Driessen E, Braak E ter, Scheele F, Slaets J, Molen T van der, Cohen-Schotanus J. Begeleiding van het portfoliogebruik in de medischebasis- en vervolgopleiding. Tijdschrift voor Medisch Onderwijs 2010;29(2):135-145.)

\section{Inleiding}

Huidige onderwijskundige inzichten ${ }^{1}$ en maatschappelijke ontwikkelingen hebben in het medisch onderwijs geleid tot een omslag van kennisgeoriënteerde naar competentiegeoriënteerde curricula. ${ }^{2-3}$ Een van de belangrijkste kenmerken van een competentiegeoriënteerd curriculum is dat studenten het eigen leerproces actief leren plannen, monitoren en evalueren. Dit zelfsturend leren is belangrijk maar ook complex en is een longitudinaal proces. ${ }^{4}$ Reflectie speelt een cruciale rol bij het stimuleren van deze zelfsturende vaardigheden. ${ }^{5}$ Het samenstellen van een portfolio wordt gezien als een belangrijk instrument om reflectieve vaardigheden te stimuleren. ${ }^{6}$ De praktijk leert echter dat het niet eenvoudig is om het gebruik van portfolio's op een succesvolle en effectieve manier te implementeren.

Uit onderzoek blijkt dat adequate begeleiding een cruciale factor is bij portfoliogebruik. $^{7-9}$ Er zijn echter maar een paar

\footnotetext{
* Dit artikel verscheen eerder onder de oorspronkelijke titel: Hanke Dekker, Erik Driessen, Edith ter Braak, Fedde Scheele, Joris Slaets, Thys van der Molen \& Janke Cohen-Schotanus. Mentoring portfolio use in undergraduate and postgraduate medical education. Med Teach 2009;31(10);903-909.
} 
studies gedaan die inzicht verschaffen in de wijze waarop het begeleidingsproces rondom portfoliogebruik is opgebouwd en daadwerkelijk verloopt. Twee kwalitatieve studies laten zien dat de leereffecten van het samenstellen van een portfolio en de interactie met de begeleider moeilijk te scheiden zijn. ${ }^{6} 10$ Pearson and Heywood beschouwen de interactie tussen lerende en begeleider over de inhoud van het portfolio als een katalysator om het verdere leren te bekrachtigen, terwijl Austin en Braidman positief rapporteren over een groepsgewijze aanpak van portfoliobegeleiding in de basisopleiding. ${ }^{11-12}$ In een door Finlay et. al uitgevoerde studie worden studenten die gedurende een periode van negen maanden een kankerpatiënt regelmatig bezoeken, ondersteund door twee maandelijkse groepsbijeenkomsten. ${ }^{13}$ Deze studenten waarderen deze groepsbijeenkomsten positief omdat het hen de gelegenheid geeft van elkaar te leren. Een cross-sectionele vergelijking tussen een traditioneel opgezet programma en een portfoliogebaseerd programma voor huisartsen, laat zien dat de opzet waarbinnen portfolio's worden gebruikt meer tegemoet komt aan de behoeften van de huisartsen. ${ }^{14}$ Een belangrijk aspect van dit programma zijn de bijeenkomsten van zes tot acht huisartsen, die onder begeleiding staan van een tutor, waarin het leren van elkaar bevorderd wordt.

Het gebruik van portfolio's in het medisch onderwijs is de laatste jaren enorm toegenomen, en vooral in Nederland waar ten gevolge van een onderwijskundige vernieuwing alle vervolgopleidingen verplicht zijn portfolio's te gebruiken bij de begeleiding van arts-assistenten. ${ }^{15}$ In de basisopleiding worden portfolio's ook steeds meer gebruikt als een begeleidingsen toetsinstrument binnen de competentiegerichte curricula. Nederlandse en Vlaamse opleiders zijn actief bezig met het nadenken over de wijze waarop portfolio's het best kunnen worden opgezet en geïmplementeerd. In een poging inzicht te krijgen in de diverse begeleidingsstructuren rondom portfoliogebruik, hebben we het begeleidingsproces van verschillende portfolioprogramma's in de basis- en vervolgopleiding in Nederland en Vlaanderen bestudeerd.

\section{Methode \\ Context}

In 2001 is de Nederlandse Vereniging voor Medisch Onderwijs (NVMO) gestart met een werkgroep Portfolio. ${ }^{16}$ Deze werkgroep is een netwerk van docenten en onderwijskundigen die betrokken zijn bij het implementeren van portfolio's. Er worden bijeenkomsten georganiseerd waar ervaringen, inzichten en onderwijsmateriaal worden uitgewisseld zodat expertise kan worden op- en uitgebouwd. In Nederland zijn acht medische basisopleidingen en in Vlaanderen vijf. Volgens de verkregen informatie worden bij acht van de dertien basisopleidingen in het Nederlandse taalgebied portfolio's gebruikt. Het aantal vervolgopleidingen is natuurlijk veel groter; deze opleidingen zijn gericht op het leren op de werkplek en worden zowel binnen academische ziekenhuizen als in zogenaamde 'teaching hospitals' verzorgd.

\section{Aanpak}

Om informatie te verzamelen over de vormgeving van het begeleidingsproces rondom het portfolio, is gekozen voor een gecombineerde aanpak van semigestructureerde interviews en een vragenlijst.

\section{Semigestructureerde interviews}

Voor de semigestructureerde interviews hebben we zes opleiders benaderd die een voortrekkersrol hebben gespeeld in het implementeren van portfolio's. Deze sleu- 
telfiguren waren alle zes actieve leden van de werkgroep Portfolio van de NVMO. Als vertegenwoordiging van de bachelorfase hebben we de coördinatoren van twee portfolioprogramma's geselecteerd; één uit Maastricht en één uit Groningen. Voor de masterfase hebben we twee coördinatoren geselecteerd uit respectievelijk het UMC Groningen en het UMC Utrecht. En als vertegenwoordiging van de vervolgopleidingen selecteerden we een opleider Obstetrie \& Gynaecologie van het VU Medisch Centrum en een opleider Interne Geneeskunde van het Universitair Medisch Centrum Groningen. De volgende onderwerpen zijn tijdens de interviews aan bod gekomen: de onderwijsdoelen van het portfolio, de positie van het portfolio binnen het curriculum, de inhoud van het portfolio, de begeleiding, de achtergronden van de portfoliobegeleiders en hun onderwijskundige ondersteuning. Deze interviews zijn gehouden door de eerste auteur. Aanvullende informatie is verzameld door middel van telefoontjes en e-mailtjes. Alle geïnterviewden zijn gevraagd het schriftelijke verslag van het interview eventueel aan te vullen en te accorderen.

\section{Vragenlijst}

De uitkomsten van deze interviews zijn gebruikt als input voor het ontwikkelen van de vragenlijst. De eerste auteur en twee coauteurs hebben de interviewuitkomsten onafhankelijk van elkaar geïnterpreteerd. Aansluitend zijn deze interpretaties uitgebreid bediscussieerd en dit leidde tot de vaststelling van de volgende hoofdonderwerpen van het begeleidingsproces rondom portfoliogebruik: 1) onderwijsdoelen van het portfoliobegeleidingsproces 2) individuele bijeenkomsten, 3) bijeenkomsten met kleine groepen studenten en 4) achtergrond/ondersteuning van de portfoliobegeleiders. Elk hoofdonderwerp is verder uitgewerkt in een aantal subvragen. Met deze vragenlijst werd de benodigde informatie verzameld over portfoliobegeleiding in de verschillende onderwijssettings. Drie onderzoekers met ervaring in het ontwerpen van vragenlijsten hebben commentaar gegeven op de conceptvragenlijst die uit 32 vragen bestond. Dit heeft erin geresulteerd dat de lijst tot 29 vragen is teruggebracht. De volgende type vragen zijn gebruikt: stellingen die beantwoord kunnen worden door middel van een vijfpuntsschaal $(1=--, 5=++)$, ja/nee vragen, multiple choice vragen en open vragen. De open vragen zijn toegevoegd om respondenten de mogelijkheid te bieden aspecten van het begeleidingsproces rondom portfoliogebruik te noemen die niet ingesloten waren in de vragenlijst.

Alle actieve leden van de werkgroep Portfolio zijn uitgenodigd om namen van docenten en onderwijskundigen door te geven die verantwoordelijkheid dragen voor de coördinatie van programma's waarin portfolio's gebruikt worden. Dit resulteerde in een lijst met e-mailadressen waarin de meerderheid van de basis- en vervolgopleidingen waarin portfolio's gebruikt worden, opgenomen is. Gekozen is voor die opleidingen waarbinnen het gebruik van portfolio's in december 2008 reeds volledig geïmplementeerd was. De vragenlijst is elektronisch verspreid onder deze coördinatoren.

\section{Analyse}

De respons op de vragenlijsten is geanalyseerd met behulp van beschrijvende statistiek. Om de leesbaarheid van de frequentietabellen te vergroten, hebben we de percentages van '+' en '++' bij elkaar opgeteld. Dit hebben we ook gedaan met de percentages van '-' en '- -'. 


\section{Resultaten Interviews}

De resultaten van de zes semigestructureerde interviews laten een grote variatie in het portfoliogebruik zien: verschillen in onderwijsdoelen en variaties wat betreft inhoud en de manier waarop portfoliogebruik georganiseerd wordt. Ook de positie die het portfolio binnen het curriculum inneemt, varieert. In de bachelorfase wordt het portfolio vaak geïmplementeerd als onderdeel van een aparte onderwijseenheid en krijgen studenten ECTS credits (European Credit Transfer System) voor een voldoende portfolio. Dit geldt ook voor de masterfase maar het portfolio is in deze fase wel veel meer geïntegreerd met de coschappen. In de vervolgopleidingen is het portfolio vaak een integraal onderdeel van de totale opleiding waarin het werkplek leren centraal staat. In elke setting heeft de begeleiding dan ook verschillende doelen. De begeleiding zelf omvat vaak individuele bijeenkomsten en groepsbijeenkomsten. In de frequentie van deze bijeenkomsten zijn grote verschillen. De meeste portfoliobegeleiders hebben een medische achtergrond. In alle portfolioprogramma's die besproken zijn tijdens de interviews, krijgen de portfoliobegeleiders onderwijskundige ondersteuning. De inhoud van dit soort trainingen laat ook weer een grote variatie zien.

Tabel 1. Begeleidingsdoelen van portfoliogebruik in de praktijk.

De student/co/assistent ...

\section{$--1-$}

(\%)

\section{$\pm$}

(\%)
N

(\%)
1. wordt geholpen en geadviseerd bij het samenstellen van het portfolio

undergraduate
postgraduate
totaal

2. krijgt feedback op het portfolio of delen ervan

3. wordt gestimuleerd te reflecteren

4. wordt begeleid bij zijn/haar competentieontwikkeling

5. wordt ondersteund bij het opstellen van een leerplan voor de komende periode

6. wordt gestimuleerd om inzicht te ontwikkelen in eigen sterke en zwakke punten

7. wordt gemotiveerd en geïnspireerd

$\begin{array}{lrrrl}\text { undergraduate } & 6 & 0 & 94 & 16 \\ \text { postgraduate } & 0 & 7 & 93 & 14 \\ \text { totaal } & 3 & 3 & 94 & 30 \\ \text { undergraduate } & 6 & 0 & 94 & 16 \\ \text { postgraduate } & 0 & 14 & 86 & 14 \\ \text { totaal } & 3 & 7 & 90 & 30 \\ \text { undergraduate } & 13 & 19 & 68 & 16 \\ \text { postgraduate } & 0 & 14 & 86 & 14 \\ \text { totaal } & 7 & 16 & 77 & 30 \\ \text { undergraduate } & 26 & 13 & 61 & 16 \\ \text { postgraduate } & 21 & 14 & 65 & 14 \\ \text { totaal } & 23 & 13 & 64 & 30 \\ \text { undergraduate } & 6 & 25 & 69 & 16 \\ \text { postgraduate } & 0 & 14 & 86 & 14 \\ \text { totaal } & 3 & 20 & 77 & 30 \\ \text { undergraduate } & 6 & 31 & 63 & 16 \\ \text { postgraduate } & 0 & 31 & 69 & 13 \\ \text { totaal } & 3 & 31 & 66 & 29\end{array}$




\section{Vragenlijst}

De vragenlijst is ingevuld door 30 respondenten die elk een ander progamma vertegenwoordigen waarbinnen portfolio's gebruikt worden.

\section{Doelen van portfoliobegeleiding}

De meest frequent genoemde doelen van portfoliobegeleiding zijn 'het geven van feedback aan de studenten over hun portfolio' (94\%) en 'het stimuleren van reflectie' $(90 \%)$. Het minst vaak genoemde doel is 'het ondersteunen van studenten bij het maken van een leerplan voor de komende periode' $(62 \%)$.

De antwoorden op de open vragen lieten nog aanvullende doelen zien zoals: 1) het meer coachen van de 'totale' student, 2) het discussiëren over emotionele, sociale en ethische aspecten, en 3) het controleren of studenten inderdaad werken aan de door hun zelf opgestelde leerdoelen.

\section{Individuele begeleiding}

In 26 programma's worden studenten individueel begeleid bij het gebruik van het portfolio. De hoeveelheid individuele bijeenkomsten, verspreid over het jaar, varieert: een of twee keer ingepland bij 14 programma's, drie of vier keer ingepland bij 10 programma's en bij twee programma's komen dit soort individuele gesprekken vijf of meer keer voor per jaar.

Meestal brengen zowel studenten (92\%) als begeleiders (81\%) gespreksonderwerpen in, en ook het terugblikken op de besproken punten van de vorige bijeenkomsten komt veel voor (84\%). In $75 \%$ van de programma's worden afspraken naar aanleiding van het gesprek op papier gezet als een soort gespreksresultaat. In de helft van de programma's wordt bovendien gewerkt met een gespreksprotocol.

De respons op de open vragen laat zien dat sommige individuele gesprekken een summatief karakter hebben. Ook wordt

Tabel 2. Aspecten van individuele begeleiding van portfoliogebruik in de praktijk.

Tijdens de individuele begeleidingsbijeenkomst ...

$--1-$

(\%)
$(\%)$
$+/++$

(\%)

1. introduceert de begeleider gespreks- undergraduate postgraduate onderwerpen op basis van het ingeleverde portfolio totaal

2. worden studenten gestimuleerd om ook gespreksonderwerpen in te brengen

undergraduate
postgraduate
totaal

3. wordt teruggeblikt op hetgeen afgesproken is tijdens de vorige bijeenkomst

undergraduate postgraduate totaal

4. wordt een vaste agenda gehanteerd

5. worden ter afsluiting de afspraken schriftelijk vastgelegd

$\begin{array}{rrrr}0 & 7 & 93 & 14 \\ 8 & 26 & 66 & 12 \\ 4 & 15 & 81 & 26 \\ 7 & 7 & 86 & 14 \\ 0 & 0 & 90 & 12 \\ 4 & 4 & 92 & 26 \\ 0 & 14 & 86 & 14 \\ 8 & 8 & 84 & 12 \\ 4 & 12 & 84 & 26 \\ 50 & 14 & 36 & 14 \\ 25 & 8 & 67 & 12 \\ 38 & 12 & 50 & 26 \\ 16 & 0 & 84 & 12 \\ 16 & 17 & 67 & 12 \\ 16 & 8 & 76 & 24\end{array}$


als doel van de individuele begeleiding de evaluatie van de ontwikkeling van de student genoemd. In de programma's waar ook kleine groepsbijeenkomsten gehouden werden, wordt ook gereflecteerd op de rol die de student heeft binnen dit groepsproces. Soms leidt een individueel gesprek nog tot een aanvullende e-mailwisseling tussen student en begeleider.

\section{Groepsbijeenkomsten}

Bijeenkomsten met een kleine groep studenten om het leren aan de hand van een portfolio te ondersteunen, komen in 16 programma 's (meestal in de bachelorfase) voor. De frequentie van deze groepssessies varieert bij 10 programma's van één tot vier bijeenkomsten, bij twee programma's van vijf tot acht bijeenkomsten en bij vier programma's van negen tot meer bijeenkomsten. De groepsgrootte varieert van zes tot elf studenten maar groepen met meer dan 12 komen ook voor (bij zes programma's). De inhoud van deze bijeenkomsten spitst zich vaak toe op het nabespreken van klinische of andere ervaringen $(68 \%)$, gevolgd door het daadwerkelijk oefenen van reflectievaardigheden (54\%) en door het oefenen in het geven en krijgen van peer feedback (50\%). Relatief weinig aandacht wordt besteed aan de wijze waarop een portfolio samengesteld moet worden (12\%).

De antwoorden op de open vragen laten zien dat er ook wel aandacht wordt besteed aan 1) het discussiëren over de persoonlijke leerstijl, 2) het discussiëren over sociale/ethische thema's en 3) aan het klinisch redeneren aangaande patiëntencasuïstiek.

\section{Portfoliobegeleiders}

De begeleiders van 27 portfolioprogramma's hebben meestal een medische achtergrond. In sommige programma's kunnen de begeleiders ook een andere achtergrond hebben, bijvoorbeeld sociale wetenschappen (tien programma's) of basiswe-

Tabel 3. Aspecten van onderwijs in kleine groepen in de praktijk.

Tijdens het onderwijs in kleine groepen ...
$--1-$

(\%)
(\%)
$\mathbf{N}$

(\%) 1. wordt het maken van een portfolio
geoefend

undergraduate
postgraduate
totaal

2. oefenen studenten/co's/assistenten in het geven en ontvangen van peer feedback

undergraduate postgraduate totaal

\section{9} 33 63

39

0

3. wordt het reflecteren geoefend

4. worden ervaringen uitgewisseld

5. wordt er geoefend met intervisie

undergraduate
postgraduate
totaal

undergraduate postgraduate totaal

$\begin{array}{lr}\text { undergraduate } & 54 \\ \text { postgraduate } & 0 \\ \text { totaal } & 50\end{array}$

$\begin{array}{rrr}16 & 15 & 13 \\ 67 & 0 & 3 \\ 25 & 12 & 16 \\ 23 & 38 & 13 \\ 0 & 100 & 3 \\ 19 & 50 & 16 \\ 15 & 62 & 13 \\ 34 & 33 & 3 \\ 19 & 56 & 16 \\ 15 & 62 & 13 \\ 0 & 100 & 3 \\ 13 & 68 & 16 \\ 9 & 37 & 11 \\ 0 & 100 & 1 \\ 8 & 42 & 12\end{array}$


tenschappen (vier programma's). De respons op de open vragen laat zien dat de portfoliobegeleider bij voorkeur onafhankelijk moet zijn. Dit houdt in dat deze begeleider niet degene is die de student ook daadwerkelijk dagelijks superviseert op de kliniek. Deze onafhankelijke begeleider moet wel een goed overzicht hebben van de doelen van het portfolio en van de inhoud en structuur van de verschillende coschappen. Een andere suggestie is dat probleemstudenten toegewezen moeten worden aan speciale begeleiders die beschikken over veel didactische vaardigheden.

Binnen 19 portfolioprogramma's wordt de begeleiders een vorm van ondersteuning aangeboden. Deze training varieert tussen schriftelijke instructie (19 programma's), één op één instructie (15 programma's), algemene didactische training van meerdere dagen (drie programma's) en een specifieke training die helemaal gericht is op het begeleiden van portfoliogebruik (13 programma's). De ondersteuning was niet alleen gericht op de nieuwe begeleiders; ook de meer ervaren begeleiders werden ondersteund. Binnen negen programma's wordt melding gemaakt van speciale sessies waar begeleiders met al enige ervaring in het begeleiden van portfoliogebruik elkaar kunnen ontmoeten en ervaringen kunnen uitwisselen. De respons op de open vragen onderstreept dat docentondersteuning cruciaal is maar wel erg tijdsintensief.

\section{Discussie}

Deze studie geeft een beschrijving van het begeleidingsproces rondom het portfoliogebruik binnen 30 basis- en vervolgopleidingen. De meeste coördinatoren van een portfolioprogramma noemen als doel van dit soort begeleiding vooral aspecten die in lijn zijn met het domein 'coaching' van het recent verschenen raamplan voor docentcompetenties ${ }^{17}$ Dit domein coaching omvat: a) verkennen van de leerbehoeften van de student, b) ondersteunen van studenten bij het definiëren en herdefiniëren van leerdoelen en het nadenken over alternatieve wegen om deze leerdoelen te bereiken, c) stimuleren van studenten tot kritische reflectie, en d) het bevorderen van het vermogen van studenten om het eigen leerproces te sturen. Alle deze deelcompetenties worden gerapporteerd in meer dan tweederde van de in dit artikel onderzochte portfolioprogramma's. Het geven van feedback is het begeleidingsdoel dat het meest gerapporteerd is. Dit is in lijn met het algemeen erkende inzicht dat feedback hét mechanisme is dat aanzet tot leren en ontwikkeling. ${ }^{18-20}$ Studenten onderstrepen dat ze behoefte hebben aan feedback op het portfolio, dit om hen te assisteren bij het vaststellen of ze op de goede weg zijn. ${ }^{8}$ Een tweede, vaak gerapporteerd begeleidingsdoel betreft het stimuleren van reflectie. Reflecteren is namelijk niet iets wat de meeste studenten al van nature doen. ${ }^{21-22}$ Studenten geven ook duidelijk aan dat ze meer begeleiding nodig hebben om juist het reflectieve aspect van het portfoliogebruik te intensiveren. ${ }^{23}$ De volgende begeleidingsdoelen worden ook relatief vaak gerapporteerd: ondersteunen van studenten bij het samenstellen van een portfolio, monitoren van hun competentieontwikkeling, helpen van studenten in het inzicht krijgen in hun sterke en zwakke punten, begeleiden van studenten bij het opstellen van een leerplan voor de komende periode en het inspireren en motiveren van studenten.

Het is onduidelijk waarom niet alle begeleidingsdoelen genoemd worden door de diverse coördinatoren. Een reden zou kunnen zijn dat sommige vormen van portfoliogebruik nog niet volledig uitontwikkeld zijn. Een andere voor de hand liggende verklaring is gerelateerd aan de inhoud van het portfolio. Als er in het portfolio geen ontwikkelingsplan hoeft worden opgeno- 
men, is het ondersteunen van studenten bij het maken van een dergelijk plan ook niet van toepassing. Toch laten de resultaten van deze studie zien dat de begeleidingsdoelen van portfoliogebruik een samenhangend geheel zijn. De manier waarop en de context waarbinnen het portfoliogebruik zich afspeelt, lijk niet erg van invloed te zijn op de begeleidingsdoelen.

De meeste studenten worden vooral individueel begeleid met het portfolio. Voor de vervolgopleidingen geldt dat het Centraal College van Medisch Specialisten zelfs voorschrijft hoeveel van dit soort individuele voortgangsgesprekken moeten worden gevoerd: vier tijdens het eerste jaar en dan afbouwend van twee per jaar in de daaropvolgende jaren tot jaarlijks één individuele bijeenkomst. Meerwaarde van de implementatie van de portfolio's is dat het ook daadwerkelijk leidt tot het inplannen en voeren van individuele begeleidingsgesprekken, vooral in de klinische setting. Dit is een positieve ontwikkeling want individuele begeleiding wordt vaak ondermijnd door de zeer volle agenda van de supervisoren. ${ }^{24}$ Een ander voordeel van de implementatie van portfolio's is dat juist de focus ligt op die individuele begeleiding; dit individuele karakter blijkt essentieel voor succesvolle begeleiding. ${ }^{25}$ De begeleider kaart op basis van het portfolio discussiepunten aan. Ook de studenten worden aangezet tot het zelf inbrengen van gespreksonderwerpen. Dit sluit aan bij het idee dat om te kunnen uitgroeien tot 'self-directed learners', studenten een actieve rol moeten spelen in het leren plannen van het eigen leerproces. ${ }^{1}$ Om ook de meer longitudinale ontwikkeling te bevorderen, is het gebruikelijk dat als afsluiting van een individueel gesprek de gesprekspunten en de gemaakt afspraken schriftelijk worden vastgelegd. Bij het daarop volgende begeleidingsgesprek wordt gestart met het evalueren van deze punten. Het werken met een vaste agenda wordt vooral binnen de vervolgopleiding als bruikbaar gezien. Dit sluit aan bij een Canadese studie waaruit de behoefte aan dit soort meer gestructureerde begeleidingsvormen naar voren komt. ${ }^{26}$ Verder onderzoek is nodig om vast te stellen wat de karakteristieken zijn van een effectief individueel begeleidingsgesprek. Een ander interessant punt voor vervolgonderzoek is het krijgen van inzicht in wat nu daadwerkelijk besproken moet worden tijdens deze gesprekken.

In de basisopleiding wordt ook gebruik gemaakt van sessies met kleine groepen studenten. Vaak wordt dit georganiseerd naast de individuele gesprekken. Dit onderwijs in kleine groepen blijkt vooral gericht op het ontwikkelen van vaardigheden die noodzakelijk zijn voor effectief portfoliogebruik. Studenten leren ervaringen in te brengen en te bespreken, en oefenen met het reflecteren. Dit type van onderwijs is van groot belang om juist dit 'reflective learning' te stimuleren. ${ }^{27-28}$ Verder onderzoek is wenselijk om te onderzoeken of studenten die in een groep hebben geleerd te reflecteren door o.a. ervaringen met elkaar te bespreken, ook meer leerwinst halen uit het gebruik van portfolio's dan studenten die dit soort groepsonderwijs niet hebben gehad.

Oefenen in het geven en ontvangen van peer feedback en intervisie blijkt minder vaak aan bod te komen tijdens deze sessies in kleine groepen. Opmerkelijk, want een studie van Mathers liet zien dat juist intervisie in het traject na de vervolgopleidingen gezien wordt als zeer ondersteunend bij het portfoliogebruik. ${ }^{14}$ Het samenstellen van het portfolio blijkt maar zeer zelden onderwerp van gesprek te zijn tijdens het onderwijs in kleine groepen terwijl dit juist wel onderkend wordt als een belangrijk begeleidingsdoel. Begeleiders zien het helpen van studenten bij het 
samenstellen van een portfolio wellicht meer als een individuele activiteit. De resultaten van onze studie laten een grote variëteit zien wat betreft de frequentie van de sessies in kleine groepen en het aantal studenten. Hoewel onderzoeksgegevens over groepsgrootte van een tutorgroep in een probleemgestuurd curriculum niet heel eenduidig zijn, wordt een groepsgrootte tussen de zes en acht studenten gezien als optimaal. ${ }^{29}$ Verder onderzoek is nodig om vast te stellen of deze groepsgrootte ook optimaal is voor het onderwijs in kleine groepen dat zich richt op het uitwisselen van ervaringen en het oefenen van reflectieve vaardigheden.

De meeste portfoliobegeleiders blijken een klinische achtergrond te hebben. In de eerste jaren van het medisch opleidingscontinuüm zijn naast clinici ook sociale en basiswetenschappers actief als begeleiders. Dit sluit aan bij een studie van Austin en Braidman die concluderen dat het niet noodzakelijk is om een klinische achtergrond te hebben om studenten te kunnen ondersteunen bij portfoliogebruik in de bachelorfase. ${ }^{12}$ Verder onderzoek is wenselijk om inzicht te krijgen in de competenties en vaardigheden die een begeleider nu nodig heeft om op een succesvolle wijze studenten te begeleiden bij het portfoliogebruik in zowel de basisals vervolgopleiding.

Het begeleiden van studenten met het portfolio is een relatief nieuwe maar cruciale taak. Het ondersteunen en professionaliseren van de begeleiders van portfoliogebruik is dan ook zeer essentieel. ${ }^{11}$ ${ }^{30}$ In de meeste contexten waarbinnen portfolio's zijn geïmplementeerd, worden de begeleiders ondersteund in deze taak. De inhoud en vormgeving van dit soort ondersteunende trainingen en trajecten vertoont een zeer brede variatie. Vier respondenten maken melding van speciaal ontwikkelde trainingen waarin de begelei- ders aan de hand van authentiek portfoliomateriaal oefenen in het kiezen van relevante onderwerpen voor het gesprek. Het daadwerkelijk gesprek wordt in dit type trainingen vaak geoefend met rollenspellen. De begeleider in spe krijgt feedback van de andere begeleiders in spe.

Sommige medische faculteiten en ziekenhuizen organiseren speciale bijeenkomsten waar de portfoliobegeleiders aangemoedigd worden ervaringen uit te wisselen en te leren van elkaar. Dit type ontmoetingen wordt in de literatuur over effectiviteit van docentprofessionalisering als zeer waardevol aangemerkt. ${ }^{31}$ Maar voor de meeste portfoliobegeleiders is de hoeveelheid beschikbare tijd voor dit soort activiteiten een beperkende factor. Het is dan ook zinvol om te kijken welke opzet van docentondersteuning zowel effectief als praktisch haalbaar is.

De kracht van deze studie is, in vergelijking tot artikelen waarin gerapporteerd wordt over maar één format van portfoliobegeleiding, dat het een overzicht geeft van het begeleidingsproces rondom portfoliogebruik binnen 30 verschillenden contexten.

Bijna alle Nederlandse en Vlaamse basisopleidingen die portfolio's hebben geïmplementeerd in hun curriculum, hebben geparticipeerd in deze studie. Het aandeel vervolgopleidingen dat heeft geparticipeerd in deze studie dekt een kleiner deel van het totale palet. Dit is deels te verklaren doordat de implementatie van het portfolio nog lang niet overal is afgerond. Een beperking van deze studie is wel dat we alleen een beschrijvend overzicht van verschillende formats van portfoliobegeleiding hebben gegeven. We hebben niet onderzocht welk format van begeleiding het leerproces van de student het meest effectief beïnvloedt. 


\section{Conclusie}

In het begeleidingproces rondom portfoliogebruik ligt een sterke focus op het geven van feedback en het stimuleren van reflectie. Studenten worden vooral individueel begeleid bij het portfoliogebruik. Soms wordt ook onderwijs in kleine groepen georganiseerd om studenten de gelegenheid te bieden ervaringen uit te wisselen en het reflecteren te oefenen. Er zijn faculteiten en ziekenhuizen die bijeenkomsten organiseren waar portfoliobegeleiders elkaar ontmoeten en kunnen leren van elkaars ervaringen en expertise. Deze studie laat zien dat het medisch onderwijs in Nederland en Vlaanderen een grote variatie heeft in het waarom, wat, waar en hoe van het begeleiden van studenten met het porfolio. Verder onderzoek is noodzakelijk om antwoord te krijgen op de vraag welke opzet van begeleiding nu het meest effectief het leerproces van de student beïnvloedt.

\section{Dankwoord}

De auteurs danken alle coördinatoren van portfolioprogramma's voor het invullen van de vragenlijst en Tineke BouwkampTimmer voor haar constructieve commentaren op het manuscript.

\section{Literatuur}

1. Dolmans DHJM, de Grave W, Wolfhagen IHAP, van der Vleuten CPM. 2005; Problem-based learning: Future challenges for educational practice and research. Med Educ 39:732-741.

2. Frank JR (Ed). The CanMEDS 2005 physician competency framework. Better standards, Better physicians, Better care. Ottawa: The Royal College of Physicians and Surgeons of Canada;2005.

3. Carraccio C, Wolfsthal SD, Englander R, Ferentz K, Martin C. Shifting paradigms: From Flexner to competencies. Acad Med 2002. 77:361-367.

4. Boekaerts M. Self-regulated learning: A new concept embraced by researchers, policy makers, educators, teachers, and students. Learn Instr 1997. 7:161-186.

5. Ertmer PA, Newby TJ. The expert learner: Strategic, self-regulated, and reflective. 1996. Instruc Sci 24:1-24.
6. Snadden D, Thomas ML. Portfolio learning in general practice vocational training: Does it work? 1998. Med Educ 32:401-406.

7. Driessen E, van Tartwijk J, van der Vleuten C, Wass V. Portfolios in medical education: Why do they meet with mixed success? A systematic review. 2007. Med Educ 41:1224-1233.

8. McMullan M. Using portfolios for clinical practice learning and assessment: The pre-registration nursing student's perspective. 2007. Nurse Educ Today 28:873-879.

9. Mansvelder-Longayroux DD, Beijaard D, Verloop $\mathrm{N}$. The portfolio as a tool for stimulating reflection by students teachers. 2006. Teach Teach Educ 23:47-62.

10. Challis M, Mathers NJ, Howe AC, Field NJ. Portfolio-based learning: Continuing medical education for general practitioners - a mid-point evaluation. 1997. Med Educ 31:22-26.

11. Pearson DJ, Heywood P. Portfolio use in general practice vocational training: A survey of GP registrars. 2004. Med Educ 38:87-95.

12. Austin C, Braidman I. Support for portfolio in the initial years of the undergraduate medical school curriculum: What do the tutors think? 2008. Med Teach 30:265-271.

13. Finlay IG, Maughan TS, Webster DJT. A randomized controlled study of portfolio learning in undergraduate cancer education. 1998. Med Educ 32:172-176.

14. Mathers NJ, Challis MC, Howe AC, Filed NJ. Portfolios in continuing medical education - effective and efficient? 1999. Med Educ 33:521-30.

15. Scheele F, Teunissen P, van Luijk S, Heineman E, Fluit L, Mulder H, Meininger A, Wijnen-Meijer M, Glas G, Sluiter H, Hummel T. Introducing competency-based postgraduate medical education in the Netherlands. 2008. Med Teach 30:248-253.

16. Ten Cate O. A National association for medical education serving the production of intellectual thought and development: Introduction to the NVMO series. 2008. Med Teach 30:235-236.

17. Molenaar WM, Zanting A, van Breukelen $P$, de Grave W, Baarne JA, Bustraan JA, Engbers R, Fick ThE, Jacobs JCG, Vervoorn JM. A framework of teaching competencies across the medical education continuum. 2009. Med Teach 31:390-96.

18. Hattie J, Timperley H. The power of feedback. 2007. Rev Educ Res 77:81-112.

19. Kluger AN, DeNisi A. The effects of feedback interventions on performance: A historical review, a meta-analysis, and a preliminary feedback intervention theory. 1996. Psychol Bull 119:254-284.

20. Van de Ridder JMM, Stokking KM, McGaghie WC, Ten Cate OTJ. What is feedback in clinical education? 2008. Med Educ 42:189-197.

21. Regehr G, Mylopoulos M. Maintaining competence in the field: Learning about practice, through 
practice, in practice. 2008. J Contin Educ Health Prof 28 Suppl 1:S19-23.

22. Driessen EW, van Tartwijk J, Vermunt JD, van der Vleuten CPM. Use of portfolios in early undergraduate medical training. 2003. Med Teach 25:18-23.

23. Davis MH, Ponnamperuma GG, Ker JS. Student perceptions of a portfolio assessment process. 2009. Med Educ 43:89-98.

24. Sambunjak, D, Straus SE, Marusíc A. Mentoring in Academic Medicine: A systematic review. 2006. JAMA 296(9):1103-1115.

25. Tobin MJ.Mentoring: Seven roles and some specifics. 2004. Am J Respir Crit Care Med 170:114-117.

26. Donovan A, Donovan J. Mentorship in postgraduates training programmes: Views of Canadian programme directors. 2009. Med Educ 43:155-158

27. Tigelaar DEH, Dolmans DHJM, de Grave WS, Wolfhagen IHAP, van der Vleuten CPM. Portfolio as a tool to stimulate teachers' reflections. 2006. Med Teach 28:277-282.

28. Schaub-de Jong MA, Cohen-Schotanus J, Dekker $\mathrm{H}$, Verkerk MA. The role of peer meetings for professional development in health science education: A qualitative analysis of reflective essays. 2009. Adv Health Sci Educ Theory Pract 14:50313.

29. Moust JHC, van Berkel HJM, Schmidt HG. Signs of erosion: Reflections on three decades of problem-based learning at Maastricht University. 2005. High Educ 50:665-683.

30. Thomé G, Hovenberg H, Edgren G. Portfolio as a method for continuous assessment in an undergraduate health education programme. 2006. Med Teach 28:e171-e176.

31. Steinert Y, Mann K, Centeno A, Dolmans D, Spencer, J, Gelula M, Prideaux D. A systematic review of faculty development initiatives designed to improve teaching effectiveness in medical education: BEME guide No. 8. Med Teach 2006. 28:497-526.
De auteurs:*

Drs. Hanke Dekker, onderwijskundige, Centrum voor Innovatie en Onderzoek Medisch Onderwijs, Universitair Medisch Centrum Groningen.

Dr. Erik Driessen, onderwijskundige en universitair docent, Capaciteitsgroep Onderwijsontwikkeling en -onderzoek, Universiteit Maastricht.

Prof. dr. Edith ter Braak, hoogleraar medisch onderwijs en plaatsvervangend opleider, Interne Geneeskunde, Universitair Medisch Centrum Utrecht.

Prof. dr. Fedde Scheele, hoogleraar Obstetrie/Gynaecologie met een speciale opdracht om medische curricula te moderniseren, VU Medisch Centrum Amsterdam. Prof $d r$. Joris Slaets, hoogleraar Geriatrie, Interne Geneeskunde, Universitair Medisch Centrum Groningen. Prof. dr. Thys van der Molen, hoogleraar chronische longziekten in de huisartsenpraktijk, Huisartsgeneeskunde, Universitair Medisch Centrum Groningen.

Prof. dr. Janke Cohen-Schotanus, hoogleraar medisch onderwijs, Centrum voor Innovatie en Onderzoek Medisch Onderwijs, Universitair Medisch Centrum Groningen.

* Alle bovengenoemde auteurs zijn betrokken bij activiteiten van de werkgroep Portfolio van de Nederlandse Vereniging voor Medisch Onderwijs.

Correspondentieadres:

H. Dekker, Centrum voor Innovatie en Onderwijs Medisch Onderwijs, Universitair Medisch Centrum Groningen, A. Deusinglaan 1, 9713 AV Groningen. Tel.:050-3638684,e-mail:h.dekker@med.umcg.nl

Belangenconflict: geen gemeld

Financiële ondersteuning: geen gemeld

\section{Summary}

Aim: Mentoring is widely acknowledged as being crucial for portfolio learning. The aim of this study is to examine how mentoring portfolio use has been implemented in undergraduate and postgraduate settings.

Method: The results of interviews with six key persons involved in setting up portfolio use in medical education programmes were used to develop a questionnaire, which was administered to thirty coordinators of undergraduate and postgraduate portfolio programmes in the Netherlands and Flanders.

Results: The interviews yielded four main aspects of the portfolio mentoring process - educational aims, individual meetings, small group sessions and mentor characteristics. Based on the questionnaire data, sixteen undergraduate and fourteen postgraduate programmes were described. Providing feedback and stimulating reflection were the main objectives of the mentoring process. Individual meetings were the favourite method for mentoring (twenty-six programmes). Small group sessions to support the use of portfolios were held in sixteen programmes, mostly in the undergraduate setting. In general, portfolio mentors were clinically qualified academics trained for their mentoring tasks. Conclusion: This study provides a variety of practical insights into implementing mentoring processes in portfolio programmes. (Dekker H, Driessen E, Braak E ter, Scheele F, Slaets, Molen T van der, Cohen-Schotanus J. Mentoring portfolio use in undergraduate and postgraduate medical education. Netherlands Journal of Medical Education 2010;29(2):135-145.) 